\title{
Relative abundance and reproductive tactics of a Loricariidae species at Saraiva Lagoon, Ilha Grande National Park, MS-PR, Brazil
}

\author{
Dayani Bailly ${ }^{1,2,4}$, Valéria Flávia Batista-Silva ${ }^{2,3}$, Milza Celi Fedatto Abelha ${ }^{2,3}$, \\ Elaine Antoniassi Luiz Kashiwaqui ${ }^{2,3}$, Carlos Alexandre Fernandes ${ }^{2,3}$ \& Edson Dias de Carvalho \\ ${ }^{1}$ Laboratório de Ecologia Teórica e Síntese, ICB1, Universidade Federal de Goiás - UFG, \\ Campus II, Goiânia, GO, Brasil \\ ${ }^{2}$ Grupo de Estudos em Ciências Ambientais e Educação - GEAMBE, Universidade Estadual de Mato \\ Grosso do Sul-UEMS, Rod. BR 163, Km 20,2, CEP 79980-000, Mundo Novo, MS, Brasil \\ ${ }^{3}$ Unidade Universitária de Mundo Novo, Universidade Estadual de Mato Grosso do Sul - UEMS, \\ Rod. BR 163, Km 20,2, CEP 79980-000, Mundo Novo, MS, Brasil \\ ${ }^{4}$ Corresponding author: Dayani Bailly, e-mail: dayanibailly@gmail.com
}

BAIlLY, D., BATISTA-SILVA, V.F., ABELHA, M.C.F., KASHIWAQUI, E.A.L., FERNANDES, C.A. \& CARVALHO, E.D. Relative abundance and reproductive tactics of a Loricariidae species at Saraiva Lagoon, Ilha Grande National Park, MS-PR, Brazil. Biota Neotropic. 11(3): http://www. biotaneotropica.org.br/v11n3/en/abstract?article+bn02811032011

\begin{abstract}
This study aimed to evaluate population abundance patterns and the main events in the reproductive cycle of Loricariichthys platymetopon at Saraiva Lagoon, Ilha Grande National Park, MS-PR, Brazil. Monthly samplings were conducted from October 2004 to September 2005 in three sections of the lagoon: entrance, middle and end, which resulted in the capture of 175 individuals. Spatial and temporal variation in abundance was obtained through CPUE (number of captured individuals $/ 1000 \mathrm{~m}^{2}$ of gillnets in 12 hours). The reproductive tactics considered were: duration, time and location of spawning, oocyte diameter and fecundity. The highest relative abundance was recorded in February, in the middle section of the lagoon, and the reproductive period lasted from September to February. The prevalence of females with spent ovaries and at rest in the following months indicated that reproductive activity ceased during autumn and winter. We observed that reproduction was high at the end section of the lagoon. The recorded mean oocyte diameter was $1.67(\mathrm{SD} \pm 0.76) \mathrm{mm}$, mean absolute fecundity was 962.1 ( $\mathrm{SD} \pm 382.48$ ) oocytes, and relative fecundity was $7.60(\mathrm{SD} \pm 2.25)$ oocytes/g and $5.13(\mathrm{SD} \pm 0.75)$ oocytes $/ \mathrm{cm}$. These tactics, probably are related to the settlement of L. platymetopom in Saraiva Lagoon, as well as in the different biotopes of the Upper Paraná River floodplain.

Keywords: fish, distribution, oocyte diameter, fecundity, reproductive period.
\end{abstract}

BAILLY, D., BATISTA-SILVA, V.F., ABELHA, M.C.F., KASHIWAQUI, E.A.L., FERNANDES, C.A. \& CARVALHO, E.D. Abundância relativa e táticas reprodutivas de uma espécie de Loricariidae da lagoa Saraiva, Parque Nacional de Ilha Grande, MS-PR, Brasil. Biota Neotropic. 11(3): http://www.biotaneotropica. org.br/v11n3/pt/abstract?article+bn02811032011

Resumo: Este estudo avaliou os padrões de abundância populacional e os principais eventos do ciclo reprodutivo de Loricariichthys platymetopon na lagoa Saraiva, Parque Nacional de Ilha Grande, MS-PR, Brasil. Foram realizadas amostragens mensais de outubro de 2004 a setembro de 2005 em três regiões: entrada, meio e final da lagoa, o que resultou na captura de 175 indivíduos. A variação espaço-temporal na abundância foi avaliada através da CPUE ( ${ }^{\circ}$ de indivíduos capturados $/ 1000 \mathrm{~m}^{2}$ rede em $12 \mathrm{~h}$ de exposição). As táticas reprodutivas avaliadas foram duração, época e local de desova, diâmetro de ovócitos e fecundidade. A maior abundância relativa foi registrada em fevereiro, na região média da lagoa e o período reprodutivo estendeu-se de setembro a fevereiro. A prevalência de fêmeas com ovários esgotados e em repouso nos meses subsequientes indicou que a atividade reprodutiva cessou no outono e inverno. Observou-se que a reprodução foi acentuada na região final da lagoa. O diâmetro médio de ovócitos registrado foi 1,67 (SD $\pm 0,76) \mathrm{mm}$, a fecundidade absoluta média 962,1 (SD \pm $382,48)$ ovócitos e a fecundidade relativa 7,60 ( $\mathrm{SD} \pm 2,25)$ ovócitos/g e 5,13 ( $\mathrm{SD} \pm$ 0,75) ovócitos/cm. Essas táticas muito provavelmente, devem estar relacionadas à ocupação da lagoa Saraiva por L. platymetopom, bem como de outros biótopos da planície de inundação do alto rio Paraná.

Palavras-chave: peixes, distribuição, diâmetro de ovócitos, fecundidade, período reprodutivo. 


\section{Introduction}

Loricariichthys platymetopon Isbrücker \& Nijssen, 1979, popularly known in Brazil as cascudo-chinelo, is found widely distributed over the La Plata River basin (Dei Tós et al. 1997, Graça \& Pavanelli 2007), which comprises the Paraná River basin. This is a fish species found both in lotic and lentic environments, preferably in the latter (lagoons) (Agostinho et al. 1997, Agostinho \& Júlio Júnior 1999). Its diet consists mainly of detritus and sediment (Fugi et al. 2001, Hahn et al. 2004) and, along with other members of the Loriicaridae family, is regarded as a trophic specialist due to adaptations in its digestive tract (ventral mouth position, sucker-shaped lips, spatular teeth, long and coiled intestine, among others) to use this kind of foods (Fugi et al. 2001). The elevated level of specialization has been appointed as an advantageous characteristic in the use on these resources, which are widely available in lentic environments (Bowen 1983, Lowe-McConnell 1999, Bennemann et al. 2000).

A common ecological attribute among detritivores, particularly those with high population abundance such as L. platymetopon, is the expressive contribution to nutrient cycling (Moore et al. 2004, Garcia \& Benedito 2010). Besides, this species was regarded as an important prey in the diet of various piscivores in the Upper Paraná River (Hahn et al. 2004), showing its ecological relevance as a link in the aquatic food chain.

There are two further peculiarities about L. platymetopon. The first is the parental care afforded to its offspring, which is done by males who carry the eggs up to the moment of hatching (Dei Tós et al. 1997). The second regards the species' success in colonizing new environments, as verified in the Upper Paraná River floodplain, where L. platymetopon currently figures among the most abundant fish species (Luiz et al. 2004, Agostinho et al. 2004, Morales et al. 2009). This species had spread from the middle Paraná River after the removal of the natural barrier of the Sete Quedas Falls, when it was flooded by the damming of the Itaipu reservoir in 1982 (Agostinho et al. 1992, 1995, 2004, Luiz et al. 2004, Júlio Júnior et al. 2009).

Further information on the abundance and reproductive biology of this species can be found in Vazzoler et al. (1997), Dei Tós et al. (1997), Quero et al. (2002, 2004), Suzuki et al. (2004), Luiz et al. (2004) and Marcucci et al. (2005). However, studies concerning this species do not exist for Ilha Grande National Park, which is a protected area of the Upper Paraná River lowlands. Of particular interest in this ecosystem is the Saraiva Lagoon, for its relevance in the region physiognomy by being one of the largest lagoons in this park (Schneider 2009), and for its characterization as a natural nursery for fish (Baumgartner et al. 2008). Considering that $L$. platymetopon is one of the most abundant species in lentic environments from the Upper Paraná River floodplain (Agostinho et al. 1995, 2004, Luiz et al. 2004), it is expected that this species is abundant and reproduces in Saraiva lagoon. Additionally, temporal variations could be observed and as this is a large lagoon, the species could occupy and reproduce in specific sections preferably. As such, this study aimed to evaluate possible spatial and temporal variations in the relative abundance and the main events of the reproductive cycle of L. platymetopon in the Saraiva Lagoon.

\section{Material and Methods}

\section{Study area}

Ilha Grande National Park, located in the Upper Paraná River floodplain, is composed by an archipelago in which Saraiva Lagoon stands out for its length close to $10,000 \mathrm{~m}$ and width ranging from 46 to $276 \mathrm{~m}$ (Figure 1). This lagoon is an environment in constant communication with the Paraná River, presenting clear waters in its entrance and dark waters in the other sections due to the presence of humic substances. The banks are steep at the beginning of the lagoon, reducing the slope along its extension. These are also lined by macrophyte stands predominantly compounded by species of the genera Eichhornia, Salvinia and Cyperus. Further details are listed in Table 1.

\section{Samplings}

Monthly samplings were conducted, from October 2004 to September 2005, at three different sections: entrance, middle and end of the lagoon (Figure 1 and Table 1).

Sampling effort was standardized always using two sets of gillnets with different mesh sizes $(3.0 ; 4.0 ; 5.0 ; 6.0 ; 7.0 ; 8.0 ; 10.0 ; 12.0 ; 14.0$; 16.0 e $20.0 \mathrm{~cm}$ between opposite nodes; $15 \mathrm{~m}^{2}$ each, with total effort of $360 \mathrm{~m}^{2} / \mathrm{section} / \mathrm{month}$ ). Samplings were undertaken during two days, always in the second fortnight of each month. Each set of nets was installed in the afternoon, in the littoral zone of the left and right margins of the respective sections, remaining exposed for 12 hours, and inspected in the morning.

For each captured individual, we registered the total length (TL) $(\mathrm{cm})$ and standard length (SL) $(\mathrm{cm})$, total weight (TW) $(0.01 \mathrm{~g})$, gonad weight $(\mathrm{GW})(0.01 \mathrm{~g})$, sex and gonadal maturation stage. The gonadal maturation scale used was immature, maturing, mature, spent and resting stages (Vazzoler, 1996). The maturity stages were determined macroscopically, based on the following gonadal characteristics: transparency, color, superficial vascularization, turgidity, volume occupied in the visceral cavity, visualization and appearance of oocytes when female, and extrusion of sperm in males. The ovaries destined for oocytes diameter and fecundity studies were fixed in formaldehyde $10 \%$. They were subsequently placed in Gilson's solution, stirring

Table 1. Characterization of the sampling sections in the Saraiva Lagoon.

\begin{tabular}{|c|c|}
\hline $\begin{array}{l}\text { Sampling } \\
\text { sections }\end{array}$ & Location and characteristics \\
\hline Entrance & $\begin{array}{l}\text { Located between coordinates } 24^{\circ} 00^{\prime} 57.9^{\prime} \text { ' S and } \\
54^{\circ} 10^{\prime} 39.4^{\prime \prime} \mathrm{W} \text {. Present extensive connection with } \\
\text { the Paraná River, which gives this area a slightly } \\
\text { lighter water color in comparison with the rest of } \\
\text { the lagoon. Both margins feature dense arboreal } \\
\text { vegetation, and macrophyte stands composed mainly } \\
\text { by Eichhornia azurea. Width is around } 60 \mathrm{~m} \text {, with } \\
\text { slightly steep banks. }\end{array}$ \\
\hline Middle & $\begin{array}{l}\text { Located between coordinates } 24^{\circ} 00^{\prime} 47.8^{\prime \prime} \mathrm{S} \text { and } 54^{\circ} \\
0.8^{\prime} 26.2^{\prime \prime} \text { W. It shows extensive stretches of aquatic } \\
\text { vegetation, especially on the right margin, which } \\
\text { features low declivity that form easily floodable plain, } \\
\text { covered with gramineae. The left margin includes, } \\
\text { beyond gramineae, little arboreal vegetation and } \\
\text { relatively steep edges. Width is approximately } 180 \mathrm{~m} \text {. }\end{array}$ \\
\hline End & $\begin{array}{l}\text { Located between coordinates } 23^{\circ} 59^{\prime} 56.5^{\prime} \mathrm{S} \text { and } \\
54^{\circ} 06^{\prime} 21.6^{\prime} \mathrm{W} \text {. It is a rather shallow stretch, with } \\
\text { herbaceous vegetation, and extensive macrophyte } \\
\text { stands. Width is about } 150 \text { to } 170 \mathrm{~m} \text {. Its margins are } \\
\text { an extensive floodplain grass-covered. Among all three } \\
\text { sampled sections, it featured the lowest mean values of } \\
\text { dissolved oxygen and water transparency. }\end{array}$ \\
\hline
\end{tabular}




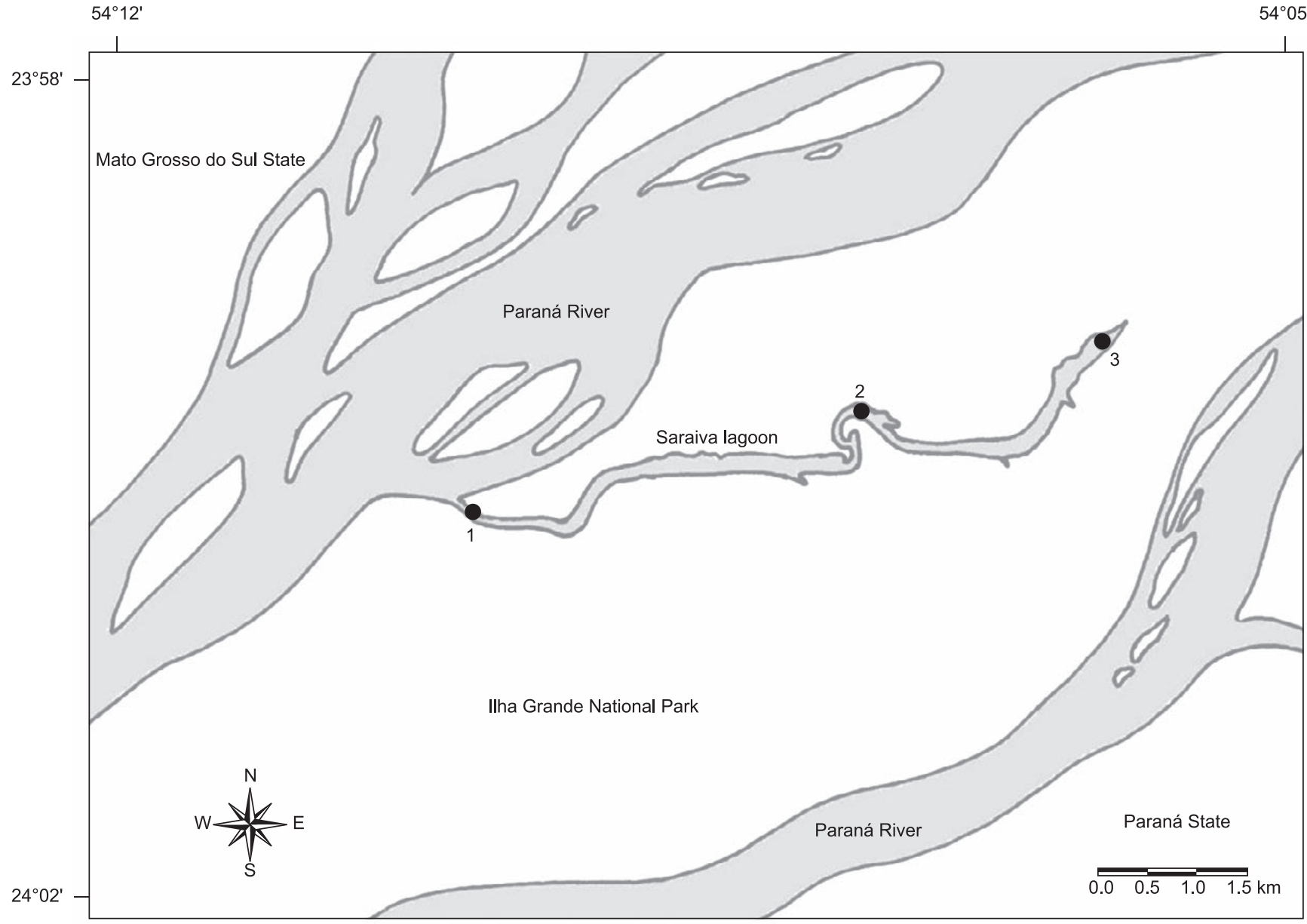

Figure 1. Location of Saraiva Lagoon in the Ilha Grande National Park. Points indicate sampling sections $(1=$ entrance, $2=$ middle, and $3=$ end $)$.

for homogenization, and left at rest for the detachment of the membrane that envelops the oocytes. After this procedure, the oocytes were preserved in alcohol $70 \%$.

Voucher specimens were deposited in the Fish Collection at the Núcleo de Pesquisa em Limnologia, Ictiologia e Aquicultura (NUPELIA) in Maringá, Paraná State, Brazil: NUP 6433.

\section{Relative abundance, reproductive attributes and data analysis}

Inferences regarding the spatial and temporal variations in the abundance of $L$. platymetopon were done based on catch per unit effort values $\left(\mathrm{CPUE}=\right.$ number of captured individuals per $1,000 \mathrm{~m}^{2}$ of gillnets in 12 hours - King (1995) of juveniles and adults for the different months and sampling sections. The CPUE was calculated using the following formula: $\mathrm{CPUE}=\mathrm{N} / \mathrm{E} * 1000$, where $\mathrm{N}$ is the number of individuals in the population, and $\mathrm{E}$ is the effort (net's area).

In this study, were considered as reproductive tactics: i) duration; ii) time; iii) location of spawning considering all adults females; iv) oocyte diameter; and v) fecundity using 10 mature females with values of Gonadosomatic Index (GSI) compatible with the maximum values pointed for this species (see Vazzoler, 1996).

The duration, time and location of spawning were evaluated through the relative frequency of the gonadal maturation stages and through monthly values of the Gonadosomatic Index (GSI) (Vazzoler
1996), which was calculated using the following formula: GSI = GW/TW * 100, where GW is the gonad weight, and TW is the total weight. This analysis considered only adult females.

In order to determine oocyte diameter and fecundity, onegram samples were taken from the total ovary weight, and oocytes were measured and counted. Oocyte diameter was established by measuring the batch of mature and hyaline oocytes in the final stage of vitellogenesis. For this, we used a stereoscopic microscope with eyepiece in millimeters. The measurements were converted to micrometers, in a 16-fold increase.

Both, absolute (number of oocytes in the pair of mature ovaries) and relative (number of oocytes per unit of weight or length) fecundity were evaluated. Absolute fecundity for the reproductive period was estimated considering the larger oocyte batches of mature ovaries, and obtained according to the formula $\mathrm{AF}=n^{*} \mathrm{GW} / \mathrm{SW}$, in which $n$ is the number of oocytes in the sample, GW is the gonad weight, and SW is the sample weight (Vazzoler 1996). Relative fecundity was obtained by dividing the absolute fecundity by the total weight and standard length of the 10 mature females chosen as described before.

In order to verify whether the GSI values differed between the sampling sections and months, and whether the mean oocyte diameters differed among the individuals, ANOVA's null model was performed using the ECOSIM (Gotelli \& Entsminger 2007) program with 10,000 randomizations. Pearson's correlation was applied to 
indicate the level of association between absolute fecundity and oocyte diameter. The significance level adopted was 0.05 .

\section{Results}

A total of 175 specimens of L. platymetopon were captured, with 121 females (99 adults and 22 immature; minimum and maximum SL: 15.0 and $29.8 \mathrm{~cm}$, respectively) and 23 males (19 adults and 4 immature; minimum and maximum SL: $15.6-24.3 \mathrm{~cm}$, respectively). Thirty-one specimens were not eviscerated, and were deposited in the fish collection at the Ichthyology Laboratory of the State University of Mato Grosso do Sul, Universitary Unity of Mundo Novo.

Regarding the temporal variation of the CPUE values, the greatest abundance was recorded in February, with constancy of high values from April to July (Figure 2). The species occurred in all three sampled sections; however, no spatial pattern was observed with regards to abundance.

Mean GSI values differed significantly over the months, and revealed that the reproductive period of $L$. platymetopon was long, from September to February (spring/summer) (Figure 3). The observation of a higher number of females with spent ovaries and rest ovaries in the subsequent months indicated that spawning ceased during autumn and winter (Figure 4).

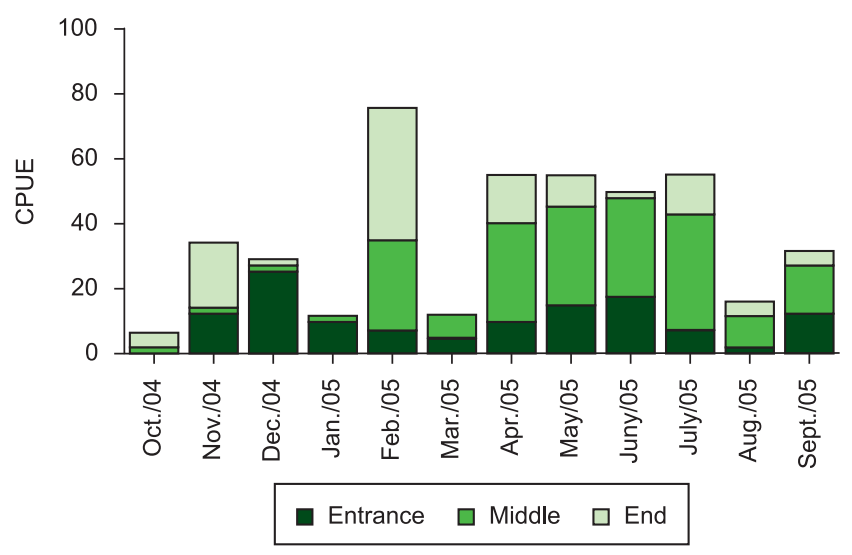

Figure 2. Total CPUE values in the different sampled sections during the study period.

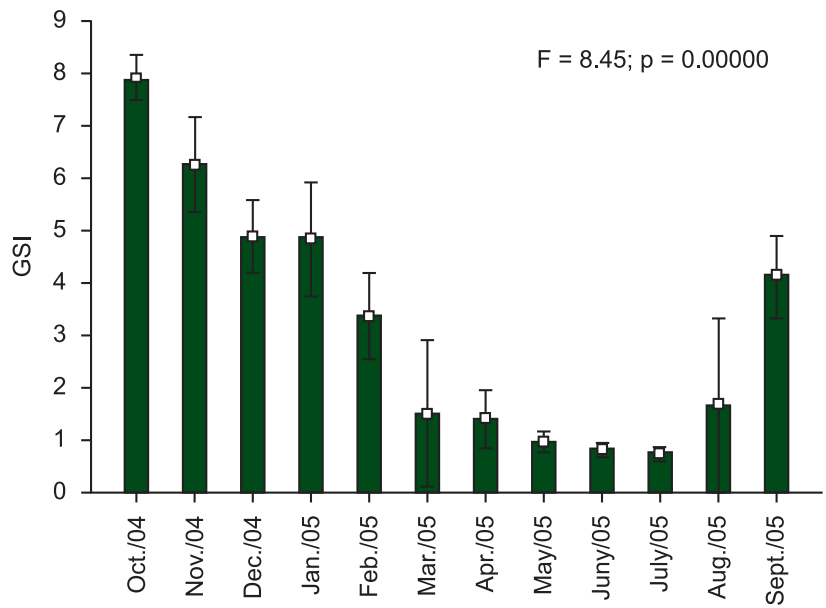

Figure 3. Mean gonadosomatic index values during the study period. Vertical bar $=$ standard error. ANOVA results were inserted in the graph.
Concerning the reproduction site, it was observed that L. platymetopon spawning was higher in the end section (Figure 5), with significant spatial differences among mean GSI values. We also verified that mature females were captured in all sections (Figure 6). Nevertheless, the highest number of mature females that also showed the heaviest ovaries was restricted to the end section.

Loricariichthys platymetopon featured large oocytes, with mean diameter varying between 1.38 and $2.16 \mathrm{~mm}$, and $1.67( \pm 0.76) \mathrm{mm}$ was the mean value recorded for the species (Figure 7). The absolute fecundity estimated for the reproductive period varied from 522.9 to 1,594.6 oocytes. Mean absolute fecundity estimated for the species was 962.1 ( $\mathrm{SD} \pm 382.48$ ) oocytes (Figure 8), and relative fecundity was $7.60(\mathrm{SD} \pm 2.25)$ oocytes/g and $5.13(\mathrm{SD} \pm 0.75)$ oocytes $/ \mathrm{cm}$.

\section{Discussion}

In order to successfully reproduce, organisms developed over time reproductive strategies with varied degrees of flexibility (tactics) to face environmental changes (Vazzoler 1996). The variability of these tactics models the strategy adopted by the species and is fundamental to their maintenance in the environment (Potts \& Wootton 1984, Vazzoler 1996, Wootton 1998). As such, the permanence of species in different habitats, reflected by abundance levels, is highly dependent on reproductive success over time (Arantes et al. 2011).



Figure 4. Relative frequency of gonadal maturation stages during the study period.

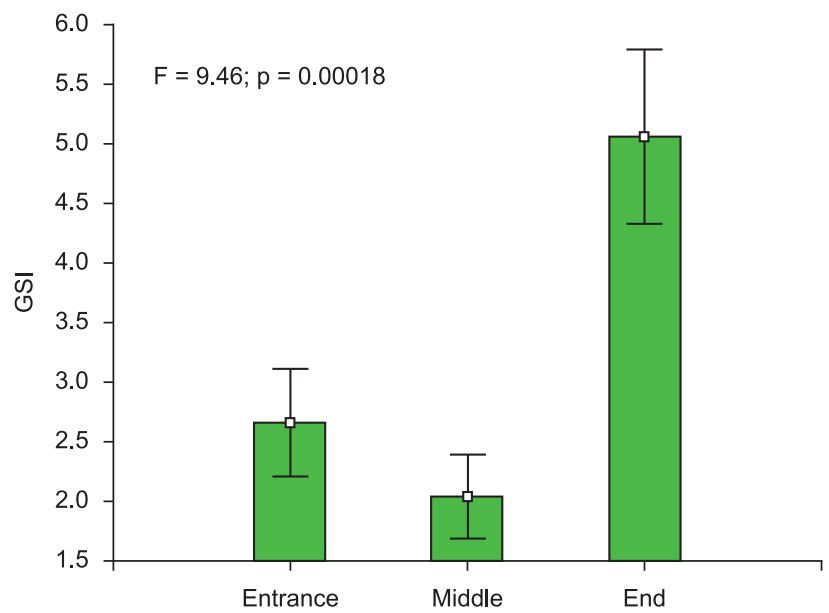

Figure 5. Mean values of the gonadosomatic index among sampled areas. Vertical bar = standard error. ANOVA results were inserted in the graph. 




Figure 6. Relative frequency of gonadal maturation stages among sampled areas.



Figure 7. Mean values of oocyte diameter $(\mathrm{mm})$ from analyzed individuals Dashed line represents the mean diameter for the species, and the vertical bar represents the standard error. ANOVA results were inserted in the graph.



Figure 8. Total fecundity (number of oocytes) for the analyzed individuals. Dashed line represents the mean fecundity for the species.
In this study Loricariichthys platymetopon was abundant. High abundance values for L. platymetopon in different biotopes of the Upper Paraná River floodplain were recorded by Agostinho et al. (1995, 2004), Luiz et al. (2004). Prior to the construction of the Itaipu Reservoir, this species was not captured in what is today upstream, and was restricted only to the Middle Paraná River (Graça \& Pavanelli 2007). However, the damming of Itaipu in 1982 culminated in the suppression of the physical barrier created by Sete Quedas Falls, which had separated two distinct ichthyofaunal provinces - Upper Paraná River and Parano-Platense (Bonetto 1986). This resulted in the dispersion of several species from the Middle to the Upper Paraná River, such as L. platymetopon, Serrasalmus marginatus, Pterodoras granulosus, Parauchenipterus galeatus, Trachydoras paraguayensis, Hypophthalmus edentatus, Ageneiosus ucayalensis, Ageneiosus inermis (Agostinho \& Júlio Júnior 1999, Graça \& Pavanelli 2007, Langeani et al. 2007), among others, altering the structure and composition of the ichthyofauna upstream (Agostinho \& Júlio Júnior 1999). Among them, L. platymetopon, $S$. marginatus and $P$. galeatus became the most abundant fish species in lagoons, rivers and channels of the Upper Paraná River floodplain (Luiz et al. 2004, Agostinho et al. 2004).

Specifically for the fish assemblage in Saraiva Lagoon, preliminary assessments indicated $L$. platymetopon as the most abundant species (unpublished data). In the results presented here, temporal variations in the abundance of this species were probably related to the fluctuations in the level of the Paraná River.

The hydrological cycle of this river, characterized by flood period during summer and dry in winter, was indicated as a key factor in determining abiotic factors as well as the density and diversity of aquatic communities (Thomaz et al. 2004). Thus, an increase in fish concentration in lagoons is expected during the dry season due to water retraction from flooded areas (Goulding 1980, LoweMcConnell 1999) and, in the particular case of sedentary species such as L. platymetopon (Suzuki et al. 2004), their confinement to the floodplain lagoons (Goulding 1980, Lowe-McConnell 1999, Agostinho et al 2004).

This must have contributed to the constancy of high capture numbers during autumn and winter. Inversely, the diluting effect of the flood (Junk et al. 1989, Neiff 1990) may have been responsible for low capture levels during the summer. However, the peak in capture recorded in February, a month in which oxygen conditions were stressful for the majority of fish (unpublished data), may be associated with the ability by $L$. platymetopon to use atmospheric oxygen as a secondary source. The presence of an accessory pocketshaped respiratory organ, attached to the digestive tract, allows this species withstand low oxygen concentrations (Silva et al. 1997). The massive capture of species with accessory aerial breathing such as Callichthys callichthys and Hoplosternum littorale (Lowe-McConnell 1999, Jucá-Chagas \& Boccardo 2006) in detriment of others in February at Saraiva Lagoon (unpublished data) gives credence to that hypothesis. Spatially, L. platymetopon showed no preference for any specific sections of the lagoon, indicating that the species uses the entire water body.

Among the most flexible reproductive tactics for fish, highlight is given to spawning period and time. These attributes can vary from one year to another, for the same species (Vazzoler 1996, Suzuki et al. 2004). Some divergences were found in the literature regarding the reproductive period of L. platymetopon (Dei Tós et al. 1997, Querol et al. 2002, Marcucci et al. 2005). Nevertheless, the prevalence of spawning between spring and summer - two seasons with a longer photoperiod, higher temperatures and greater rainfall - was a common characteristic observed in the these studies, as was the case for this species at Saraiva Lagoon. 
In regards to the spatial variation of spawning, the presence of mature females in all three sampled sections suggests that this event took place throughout the entire biotope. It should be stressed that Saraiva Lagoon is an important site for fish larvae survival (Gogola et al. 2010), including L. platymetopon (Baumgartner et al. 2008). This environment was regarded by Nakatani et al. (2004) as a natural nursery, due to its high density of ichthyoplankton kept by the abundant aquatic vegetation in the margins, acting as a source of shelter and food. The prevalence of females with heavier ovaries at the end of the lagoon suggests that spawning is concentrated in this section. Among the sampled sections, it is the shallowest, with the lowest levels of transparency and dissolved oxygen. The reproduction of L. platymetopon in turbid and hypoxic environments was equally reported by Dei Tós et al. (1997). Such conditions can hinder the development of eggs and larvae if there is no water renewal; however, they can reduce mortality from predation, as they prevent the action of visual predators (Agostinho et al. 1992). Under conditions of hypoxia, the swimming movements of males carrying offspring to areas with more oxygen represent an essential factor in aerating the eggs (Freire \& Agostinho 2000), thus warranting the necessary oxygen for their development.

Parental care in fish shows varied degrees of offspring protection, from adhesive eggs deposition in specific substrates, building and maintaining nests, oral incubation, to egg adhesion to the parental structures, and can be performed by the couple or by only one of the individuals (Smith \& Wootton 1995, Wootton 1998, Gross 2005, Rushbrook et al. 2010). In the particular case of L. platymetopon, this task is attributed to males, which carry the eggs until hatching time. During the reproductive period, the species features an accentuated sexual dimorphism characterized by increase of the lip structures formed in the ventral area of males, where eggs remain attached (Dei Tós et al. 1997). This type of parental care appears to be common among Loricariidae (Py-Daniel \& Cox Fernandes 2005), and has been recorded for L. typus (Machado-Allison \& Lopes-Rojas 1975, Machado-Allison 1990), L. anus (Bruschi-Júnior et al. 1997) and L. apixii (Duarte et al. 2007). For Megalancystrus aculeatus and Hypostomus ternetzi, males guard the nests where the adhesive eggs are laid (Suzuki et al. 2000).

Much information on the reproductive strategy of fish is contained in the ovaries, specifically in the oocytes. Their diameter can reflect the level of parental care developed by a species - egg size increases with the quality (duration) of such care (Gross \& Sargent 1985, Sargent et al. 1987). Positive relationships were observed between egg size and offspring survival rates (Ahnesjö 1992). In addition to having higher survival rates, clutches resulting from large eggs are more resistant to starvation (Ahnesjö 1992). Furthermore, there is also an inverse relationship between fecundity and oocyte diameter, in that species with larger oocytes are less fertile (Duarte \& Alcarraz 1989, Adebisi 1990).

Loricariichthys platymetopon females at Saraiva Lagoon showed scarce but large oocytes. Species with parental care tend to produce large oocytes and in lower number (Winemiller \& Rose 1992, Suzuki 1992, Kolm \& Ahnesjö 2005). This reduced fecundity is compensated by the high energy invested in caring for and protecting the eggs, as they take longer to hatch. When compared to other females of the same species, the diameter and absolute fecundity values were lower than those recorded by Marcucci et al. (2005) and Suzuki et al. (2000), while the relative fecundity value was intermediary compared to that found in these two studies. It is worth mentioning that fecundity is a subjective measurement, especially for parceled spawning species such as L. platymetopon (Suzuki et al. 2000). This is related to the uncertainty of how many batches and oocytes had been eliminated up to the moment of capture.
The high abundance of L. platymetopon at Saraiva Lagoon, as well as at other biotopes of the Upper Paraná River floodplain, is linked to several factors, among them, stands out those related with feeding and reproductive strategies. Multiple spawning, extended over a long reproductive period, may contribute to the species recruitment, maintaining its numeric abundance. Allied to that, the intense parental care possibly contributes to increase egg viability, as well as the chances of survival for larvae and juveniles (Wootton 1998). The fact that $L$. platymetopon requires a single type of environment to complete its life cycle, thus eliminating the stress caused by migration, and its independence from floods for spawning, should adds great advantages for this species in maintaining its stocks in lentic environments.

In addition, future researches about the influence of abiotic factors on abundance and reproductive attributes of L platymetopon at Saraiva Lagoon would be invaluable for the establishment of patterns underlying those herein suggested.

\section{Acknowledgements}

The authors wish to thank the FUNDECT for financial support, to CORIPA and to the Mundo Novo Municipal Government for logistical support. We are also grateful to Ph. D. Harumi Irene Suzuki (State University of Maringá - Nupélia) for the assistance in obtaining oocytes diameter, fecundity data and the manuscript review.

\section{References}

ADEBISI, A.A.A. 1990. A mathematical expression for the estimation of relative fish fecundity using oocyte size. Rev. Biol. Trop. 38:323-324.

AGOSTINHO, A.A. \& JÚLIO-JÚNIOR, H.F.1999. Peixes da bacia o alto rio Paraná. In Estudos Ecológicos de comunidades de peixes tropicais (R.H. Lowe-McConnell, ed.). EdUSP, São Paulo, p.347-400.

AGOSTINHO, A.A., BINI, L.M., GOMES, L.C., JÚLIO-JÚNIOR, H.F., PAVANELLI, C.S. \& AGOSTINHO, C.S. 2004. Fish assemblages. In The upper Paraná River and its floodplain: physical aspects, ecology and conservation (S.M. Thomaz, A.A. Agostinho \& N.S. Hahn, eds.). Backhuys Publishers, Leiden, p.223-246.

AGOSTINHO, A.A., JÚLIO-JÚNIOR, H.F. \& BORGHETTI, J.R. 1992. Considerações sobre os impactos dos represamentos sobre a ictiofauna e medidas para sua atenuação. Um estudo de caso: Reservatório de Itaipu. Rev. Unimar 14(suppl.):89-107.

AGOSTINHO, A.A., JÚLIO-JÚNIOR, H.F., GOMES, L.C., BINI, L.M. \& AGOSTINHO, C.S. 1997. Composição, abundância e distribuição espaçotemporal da ictiofauna. In A planície de inundação do ato rio Paraná: aspectos físicos, biológicos e socioeconômicos (A.E.A.M. Vazzoler, A.A. Agostinho \& N.S. Hahn, eds.). EDUEM, Maringá, p.179-208.

AGOstinHO, A.A., VAZZOLER, A.E.A.M. \& THOMAZ, S.M. 1995. The high River Paraná basin: limnological and ichtyological aspects. In Limnology in Brazil (J.G. Tundisi, C.E.M. Bicudo \& T. MatsumuraTundisi, eds.). ABC/SBL, Rio de Janeiro, p.59-103.

AHNESJÖ, I. 1992. Fewer newborn result in superior juveniles in the paternally brooding pipefish Syngnathus typhle L. J. Fish Biol. 41(B):53-63.

ARANTES, F.P., SANTOS, H.B., RIZZO, E., SATO, Y. \& BAZZOLLI, N. 2011. Collapse of there productive process of two migratory fish (Prochilodus argenteus and Prochilodus costatus) in the Tres Marias Reservoir, Sao Francisco River, Brazil. J. Appl. Ichthyol. 27:847-853. http://dx.doi.org/10.1111/j.1439-0426.2010.01583.x

BAUMGARTNER, G., NAKATANI, K., GOMES, L.C., BIALETZKI, A., SANCHES, P.V. \& MAKRAKIS, M.C. 2008. Fish larvae from the upper Paraná River: do abiotic factors affect larval density? Neotrop. Ichthyol. 6(4):551-558. http://dx.doi.org/10.1590/S1679-62252008000400002

BENNEMANN, S.T., SHIBATTA, O.A. \& GARAVELLO, J.C. 2000. Peixes do rio Tibagi: uma abordagem ecológica. EDUEL, Londrina. 
BONETTO, A.A. 1986. The Paraná River system. In The ecology of river systems (B.R. Davies \& K.F. Walker, eds.). Dr. W. Junk Publishers, Dordrech, p.541-555.

BOWEN, S.H. 1983. Detritivory in neotropical fish communities. Environ. Biol. Fish. 9:137-144. http://dx.doi.org/10.1007/BF00690858

BRUSCHI-JUNIOR, W., PERET, A.C., VERANI, J.R. \& FIALHO, C.B. 1997. Reprodução de Loricariichthys anus (Valenciennes, 1840) da Lagoa Emboaba, Osório, RS, Brasil. Rev. Bras. Biol. 57(4):677-685.

DEI TÓs, C., AGOSTINHO, A.A. \& SUZUKI, H.I. 1997. Population structure and reproductive biology of Loricariichthys platymetopon (Siluriformes, Pisces) from Upper Paraná River. Braz. Arch. Biol. Technol. 40(4):793-807.

DUARTE, C.M. \& ALCARAZ, M. 1989. To produce many small or few large eggs: a size-independent reproductive tatic of fish. Oecologia 80:401-404. http://dx.doi.org/10.1007/BF00379043

DUARTE, S., ARAÚJO, F.J., SALES, A. \& BAZZOLI, N. 2007. Morphology of gonads, Maturity and Spawning Season of Loricariichthys spixii (Siluriformes, Loricariidae) in a Subtropical Reservoir. Braz. Arch. Biol. Technol. 50(6):1019-1032. http://dx.doi.org/10.1590/S151689132007000700013

FREIRE, A G. \& AGOSTINHO, A.A. 2000. Distribuição espaço temporal de 8 espécies dominantes da ictiofauna da bacia do alto rio Paraná. Acta Limnol. Bras. 12:105-120.

FUGI, R., AGOSTINHO, A.A. \& HAHN, N.S. 2001. Trophic morfology of five benthic-feeding fish species of a tropical floodplain. Rev. Bras. Biol. 61(1):27-33. http://dx.doi.org/10.1590/S0034-71082001000100005

GARCIA, D.A. \& BENEDITO, E. 2010. Variation in energy density of Loricariichthys platymetopon (Siluriformes: Loricariidae) in the upper Paraná River basin. Neotrop. Ichthyol. 8(2):321-327. http://dx.doi. org/10.1590/S1679-62252010000200010

GOGOLA, T.M., DAGA, V.S., SILVA, P.R.L., SANCHES, P.V., GUBIANI, E.A., BAUMGARTNER, G. \& DELARIVA, R.L. 2010. Spatial and temporal distribution patterns of ichthyoplankton in a region affected by water regulation by dams. Neotrop. Ichthyol. 8(2):341-34. http://dx.doi. org/10.1590/S1679-62252010000200013

GOTELLI, N.J. \& ENTSMINGER, G.L. 2007. ECOSIM: Null models software for ecology. Version 7.0. Acquired Intelligence Inc. \& KeseyBear. http://homepages.together.net/ gentsmin/ecosim.htm.

GOULDING, M. 1980. The fishes and the forest: Explorations in Amazon Natural History. University of California Press, Berkeley.

GRAÇA, W.J. \& PAVANELLI, C.S. 2007. Peixes da planície de inundação do alto rio Paraná e áreas adjacentes. EDUEM, Maringá.

GROSS, M. \& SARGENT, R. 1985. The evolution of male and female parental care in fishes. Am. Zool. 25:807-22. PMid:15884734. http:// dx.doi.org/10.1086/431023

GROSS, M.R. 2005. The evolution of parental care. Quart. Rev. Biol. 80(1):37-46.

HAHN, N.S., FUGI, R. \& ANDRIAN, I.F. 2004. Trophic ecology of the fish assemblages. In The Upper Paraná River and its floodplain: physical aspects, ecology and conservation (S.M. Thomaz, A.A. Agostinho \& N.S. Hahn, eds.). Backhuys Publishers, Leiden, p.247-269.

JUCÁ-CHAGAS, R. \& BOCCARDO, L. 2006. The air-breathing cycle of Hoplosternum littorale (Hancock, 1828) (Siluriformes: Callichthyidae). Neotrop. Ichthyol. 4(3):371-373.

JÚLIO-JÚNIOR, H.F., DEI TÓS, C., AGOSTINHO, A.A. \& PAVANELLI, C.S. 2009. A massive invasion of fish species after eliminating a natural barrier in the upper rio Paraná basin. Neotrop. Ichthyol. 7(4):709-718.

JUNK W.J., BAYLEY P.B. \& SPARKS, R.E. 1989. The flood pulse concept in river floodplain systems. Can. Sp. Publ. Fish. Aquat. Sci. 106:110-127.

KING, M. 1995. Fisheries biology: assessment and management. Fishing News Book, Oxford

KOLM, N. \& AHNESJÖ, I. 2005. Do egg size and parental care coevolve in fishes? J. Fish Biol. 66:1499-1515. http://dx.doi.org/10.1111/j.00221112.2005.00777.x
LANGEANI, F., CASTRO, R.M.C., OYAKAWA, O.T., SHIBATTA, O.A., PAVANELLI, C.S. \& CASATTI, L. 2007. Diversidade da ictiofauna do Alto Rio Paraná: composição atual e perspectivas futuras. Biota Neotrop. 7(3): http://www.biotaneotropica.org.br/v7n3/pt/ abstract?article+bn03407032007 (ultimo acesso em 01/12/2010)

LOWE-McCONNELL, R.H. 1999. Estudos ecológicos de comunidades de peixes tropicais. EdUSP, São Paulo.

LUIZ, E.A., GASPAR DA LUZ, K.D., COSTA, R.S., LATINI, J.D., JÚLIOJÚNIOR, H.F. \& GOMES, L.C. 2004. Structure of the fish assemblage in biotopes and subsystems of the upper Paraná River Floodplain. In Structure and functioning of the Paraná River and its floodplain (A.A Agostinho, L. Rodrigues, L.C. Gomes, S.M. Thomaz \& L.E. Miranda, eds.). EDUEM, Maringá, p.117-124.

MACHADO-ALLISON, A. \& LOPEZ-ROJAS, H. 1975. Etapas del desarollo de Loricariichthys typus (Bleeker, 1864) (Osteichthyes, Siluriformes, Loricariidae). Acta Biol. Venez. 9(1): 93-119.

MACHADO-ALLISON, A. 1990. Ecología de los peces de las areas inundables de los llanos de Venezuela. Interciencia 15(6):411-423.

MARCUCCI, K.M.I., ORSI, M.L. \& SHIBATTA, O.A. 2005. Abundância e aspectos reprodutivos de Loricariichthys platymetopon (Siluriformes, Loricariidae) em quatro trechos da represa Capivara, médio rio Paranapanema. Iheringia 95(2):197-203. http://dx.doi.org/10.1590/ S0073-47212005000200010

MOORE, J.C., BERLOW, E.L., COLEMAN, D.C., RUITER, P.C., DONG, Q., HASTINGS, A., JOHNSON, N.C., MCCANN, K.S., MELVILLE, K., MORIN, P.J., NADELHOFER, K., ROSEMOND, A.D., POST, D. M., SABO, J.L., SCOW, K.M., VANNI, M.J. \& WALL, D.H. 2004 Detritus, trophic dynamics and biodiversity. Ecol. Lett, 7:584-600. http:// dx.doi.org/10.1111/j.1461-0248.2004.00606.x

MORALES, B.F., BENEDITO, E. \& OLIVEIRA, E.F. 2009. Composição e estrutura da ictiofauna. In Ecologia do ribeirão Diamante: Estação Ecológica do Caiuá/PR (E. Benedito, ed.) EDUEM, Maringá, p.85-105.

NAKATANI, K., BIALETZKI, A., BAUMGARTNER, G., SANCHES, P.V. \& MAKRAKIS, M.C. 2004. Temporal and spatial dynamics of fish eggs and larvae. In The upper Paraná River and its floodplain: physical aspects, ecology and conservation (S.M. Thomaz, A.A. Agostinho \& N.S. Hahn, eds.). Backhuys Publishers, Leiden, p.295-308.

NEIFF, J.J. 1990. Ideas para la interpretacion ecologica del Paraná. Interciência 15:424-441.

POTTS, G.W. \& WOOTTON, R.J. 1984. Fish Reproduction: strategies and tactics. London, Academic Press, 410p.

PY-DANIEL, L.R. \& COX-FERNANDES, C. 2005. Dimorfismo sexual em Siluriformes e Gymnotiformes (Ostariophysi) da Amazônia. Acta Amaz. 35(1):97-110. http://dx.doi.org/10.1590/S0044-59672005000100015

QUEROL, M.V.M., QUEROL, E. \& GOMES, N.N.A. 2002. Fator de condição gonadal, índice hepatossomático e recrutamento como indicadores do período de reprodução de Loricariichthys platymetopon (Osteichthyes, Loricariidae), bacia do rio Uruguai médio, sul do Brasil. Iheringia 92(3):79-84. http://dx.doi.org/10.1590/S0073-47212002000300008

QUEROL, M.V.M., QUEROL, E. \& PESSANO, E.F. 2004. Influência de fatores abióticos sobre a dinâmica da reprodução do cascudo viola Loricariichthys platymetopon (Isbrucker \& Nijssen, 1979) (Osteichthyes, Loricariidae), no reservatório da estância Nova Esperança, Uruguaiana, bacia do Rio Uruguai, RS, Brasil. Biodivers. Pampeana 2:24-29.

RUSHBROOK, B.J., HEAD, M.L., KATSIADAKI, I. \& BARBER, I. 2010. Flow regime affects building behaviour and nest structure in sticklebacks. Behav. Ecol. Sociobiol. 64:1927-1935 . http://dx.doi.org/10.1007/ s00265-010-1003-3

SARGENT, R.C., TAYLOR, P.D. \& GROSS, M.R. 1987. Parental care and the evolution of egg size in fishes. Am. Nat. 129(1):32-46. http://dx.doi. org/10.1086/284621

SCHNEIDER, M.M.M. 2009. O Parque Nacional De Ilha Grande, produção e consumo do território turístico. Dissertação de mestrado, Universidade Federal da Grande Dourados, Dourados. 
Bailly, D. et al.

SILVA, J.M., HERNANDEZ-BLAZQUEZ, F.J. \& JÚLIO-JÚNIOR, H.F. 1997. A new accessory respiratory organ in fishes: morfology of the respiratory purses of Loricariichthys platymetopon (Pisces, Loricariidae). Ann. Sci. Natur. 18(3):93-103.

SMITH, C. \& WOOTTON, R.J. 1995. The costs of parental care in teleost fishes. Rev. Fish Biol. Fish. 5:7-22. http://dx.doi.org/10.1007/ BF01103363

SUZUKI, H.I. 1992. Variações na morfologia ovariana e no desenvolvimento no folículo de peixes teleósteos da bacia do rio Paraná. Dissertação de mestrado, Universidade Federal do Paraná, Curitiba.

SUZUKI, H.I., AGOSTINHO, A.A. \& WINEMILLER, K.O. 2000. Relationship between oocyte morphology and reproductive strategy in loricariid catfishes of the Paraná River, Brazil. J. Fish Biol. 57:791-807.

SUZUKI, H.I., VAZZOLER, A.E.A.M., MARQUES, E.E., PEREZ-LIZAMA, M.A. \& INADA, P. 2004. Reproductive ecology of the fish assemblages. In The upper Paraná River and its floodplain: physical aspects, ecology and conservation (S.M. Thomaz, A.A. Agostinho \& N.S. Hahn, eds.). Backhuys Publishers, Leiden, p. 271-292
THOMAZ, S.M., PAGIORO, T.A., BINI, L.M., ROBERTO, M.C. \& ROCHA, R.R.A. 2004. Limnological characterization of the aquatic environments and the influence of hydrometric levels. In The upper Paraná River and its floodplain: physical aspects, ecology and conservation (S.M. Thomaz, A.A. Agostinho \& N.S. Hahn, eds.). Backhuys Publishers, Leiden, p. 75-102.

VAZZOLER, A.E.A.M. 1996. Biologia da Reprodução de Peixes Teleósteos: Teoria e Prática. EDUEM, Maringá.

VAZZOLER, A.E.A.M., SUZUKI, H.I., MARQUES, E.E. \& PEREZLIZAMA, M.A. 1997. Primeira maturação gonadal, períodos e áreas de reprodução. In A planície de inundação do alto rio Paraná: aspectos físicos, biológicos e socioeconômicos (A.E.A.M.Vazzoler, A.A. Agostinho \& N.S. Hahn, eds). EDUEM, Maringá, p. 249-265.

WINEMILLER, K.O. \& ROSE, K.A. 1992. Patterns of life-history diversification in North American fishes: implications for population regulation. Can. J. Fish. Aquat. Sci. 49(10):2196-2218. http://dx.doi. org/10.1139/f92-242

WOOTTON, R.J. 1998. Ecology of Teleost Fishes. 2nd ed. Kluwer Academic Publishers, London. 